\title{
Bond Yield Spillovers from Major Advanced Economies to Emerging Asia*
}

\author{
Ansgar Belke \\ (University of Duisburg-Essen and Centre for European Policy Studies, Brussels) \\ Irina Dubova \\ (University of Duisburg-Essen and Ruhr Graduate School, Essen) \\ Ulrich Volz \\ (SOAS University of London and German Development Institute, Bonn)
}

February 27, 2017

\begin{abstract}
This paper explores the extent to which changes to long-term interest rates in major advanced economies have influenced long-term government bond yields in Emerging Asia. To gauge long-term interest spillover effects, the paper uses VAR variance decompositions with high frequency data. Our results reveal that sovereign bond yields in Emerging Asia responded significantly to changes to US and Eurozone bond yields, although the magnitudes were heterogeneous across countries. The size of spillovers varied over time. The pattern of these variations can partially be explained by the implementation of different unconventional monetary policy measures in advanced countries.
\end{abstract}

JEL codes: E52, E58, F42

Keywords: Long-term interest rates, bond yields, monetary policy spillovers, Emerging Asia

Corresponding author: Ulrich Volz, SOAS University of London, Thornhaugh Street, Russell Square, London WC1H 0XG, UK. T: +44 (0)207 898 4721. Email: uv1@soas.ac.uk.

* Acknowledgments: We would like to thank participants of the ADBI’s 2016 Annual Conference on "The Implications of Ultra-low and Negative Interest Rates for Asia" for helpful comments and suggestions, especially our discussant Masazumi Hattori, as well as Tamim Bayoumi and Naoyuki Yoshino. All remaining errors are our own. 


\section{Introduction}

For a number of years, the central banks of the major advanced economies have pursued historically unprecedented ultra-low interest rate policies and negative interest rate policies; facing the zero lower bound problem, they have also implemented various asset purchase programs - known as "quantitative easing” (QE) - with the aim of reducing long-term interest rates. While there is a continuing debate on the relation between short-term and long-term interest rates (Roley and Sellon, 1995; Wright, 2012) as well as the effect of QE policies on long-term rates (Belke et al., 2016, Krishnamurthy and Vissing-Jorgensen, 2011; Christensen and Rudebusch, 2012; Christensen and Krogstrup, 2015; Gros et al., 2015), there has been growing evidence that advanced countries' unconventional monetary policies (UMPs) have caused significant spillovers to the financial markets of emerging market economies (EMEs).1

Importantly, the decline in short- and long-term government yields in advanced countries has contributed to the flow of investment funds into EME assets with higher risk-adjusted returns. Such additional flows of funds into emerging market bonds may influence domestic monetary conditions by altering long-term yields in emerging countries. Furthermore, some EMEs recently have experienced increases in foreign investment in conjunction with growth in both the liquidity and principal outstanding in their local currency government bond markets, potentially increasing the link between foreign and domestic interest rates via portfolio reallocations between developed and emerging bond markets (Moore et al., 2013).

Against this backdrop, this paper investigates the evolution of spillovers from advanced countries' bond markets to EMEs. The analysis and quantification of these spillovers provides insights into the degree of monetary independence that EMEs enjoy. To gauge long-term interest spillover effects, the paper uses vector autoregressive (VAR) variance decompositions with daily data for eight Asian emerging economies (China, India, Indonesia, Korea, Malaysia, the Philippines, Taiwan and Thailand)2 as well as Hong Kong, the US, the Euro area and Japan for the period May 2003 to September 2016.

1 See Chen et al. (2012), Lavigne et al. (2014), Miyajima et al. (2014), Bowman et al. (2015), Eichengreen and Gupta (2015), Hofmann and Takáts (2015), Tillmann (2016) and Caceres et al. (2016).

2 These eight Asian economies are included in the widely used Modern Index Strategy Indexes (MSCI) Emerging Markets Index. Hong Kong is considered a developed market by MSCI. 
In contrast to previous studies looking into monetary policy spillovers to EMEs, we use highfrequency data, the dynamics of which are less affected by macroeconomic fundamentals. This is an advantage in identifying spillovers in financial markets, where news are priced rapidly. Given a much larger number of observations as compared to using data at lower frequency, we are also able to better analyze the time-variations in the spillovers and detect sudden changes in transmission magnitudes.

Apart from event studies which are usually based on daily (or intra-daily) data, most empirical investigations of interest rate spillovers from the advanced countries to EMEs use monthly or quarterly data (Belke et al., 2016). To our knowledge, the only non-event study where high frequency data is used to investigate interest rate spillovers from the US to EMEs is Edwards(2012). However, there are a number of important differences between our analysis and that conducted by Edwards (2012). Firstly, Edwards analyses spillovers from the US to seven EMEs, only three of which are Asian (Indonesia, Korea, and the Philippines), while we analyze spillovers to eight Asian EMEs plus Hong Kong. Secondly, while Edwards investigates only spillovers from the Fed's monetary policies to EMEs, we are interested also in potential interest rate pass-through from the Euro area and Japan, respectively. Thirdly, Edwards covers only the relatively tranquil period of the "great moderation" using data from January 2000 until the second week of September 2008 while our analysis includes also the time when the Fed, the European Central Bank (ECB) and the Bank of Japan (BOJ) embarked on UMPs on an unprecedented scale. Fourthly, Edwards looks into short-term interest rates while we investigate long-term rates. Fifthly, we use daily data, in contrast to the weekly data used by Edwards. And, finally, Edwards uses GLS and GMM estimations whereas we follow a completely different empirical approach based on Vector-autoregressions (VARs).

In this paper we construct measures of spillover intensities from major advanced countries to Emerging Asia and analyze their time-variations against the backdrop of monetary policy changes or announcements in advanced economies. This study is not an event study, since we do not model particular announcements, but rather scrutinize the dynamics of the co-movements between longterm interest rates over a timeframe during which major central banks conducted a number of UMPs. Our results show that sovereign bond yields in Emerging Asia are significantly affected by changes in US and Eurozone bond yields, although the magnitude of spillovers varied substantially over time and across countries. Whereas the turning points in the intensity of spillovers from the 
US appear to be directly related to the Fed's monetary policy, the results for the Euro area and Japan spillovers turn out to be heterogeneous across Emerging Asia.

The remainder of this paper is organized as follows. Section 2 provides a brief discussion of bond markets in Emerging Asia and a review of the literature on monetary policy spillovers between advanced and emerging economies. Section 3 outlines our estimation approach and the data and variables we use. Section 4 presents our estimations of bond yield spillovers. Section 5 sums up our findings and discusses policy implications.

\section{Bond markets in Emerging Asia and monetary policy spillovers}

Bond markets play an important role in building a diversified financial system and promoting longterm financing to support growth. Since the late 1990s, EMEs have recognized the importance of local currency bond markets and promoted their development, especially government bond markets. 3 In Emerging Asia, local currency government bonds have become an increasingly important source of government financing. Foreign investors have continuously strengthened their exposure to government bond markets in emerging economies.

Movements in bond yields across the region can be attributed both to fundamental conditions in domestic economies and the influence of global factors. Economic growth, inflation and fiscal conditions should be mentioned among the main domestic factors (Jaramillo and Weber, 2012). Recently, low interest rate environments in the advanced economies resulted in favorable liquidity conditions and have driven foreign investors to riskier assets in search of higher expected riskadjusted returns (Belke and Verheyen, 2014). Such portfolio rebalancing has lowered risk premiums, boosted asset prices and lowered yields in the Emerging Asia, effectively easing the financial conditions in the region and thus, creating challenges for their central banks in delivering price and financial stability.

Along with the portfolio-balance channel, Bauer and Rudebusch (2014) stress the importance of the signaling channel starting in 2008. Since large interest rate differentials with respect to Emerging Asia were expected to persist over a considerable time period, it has prompted carry trades and capital flows into the region.

3 For an overview of efforts in developing local currency bond markets in Asia see Park (forthcoming). 
Some studies argue that indeed a large part of movements in emerging market spreads are due to outside factors such as global liquidity and risk appetite (Gonzales-Rozada and Levy-Yeyati, 2008). This poses potential adverse effects on Emerging Asia economies if, firstly, movements in bond yields are determined more by global factors rather than by changes in domestic economic conditions, including domestic monetary policy (Belke and Rees, 2014); and secondly, the volatility from global bond markets is transmitted to domestic bond markets, posing challenges for financial stability. Indeed, there is now a growing empirical literature on international monetary policy transmission, showing that a prolonged period of very accommodative monetary policy in the US and other major advanced economies has impacted on financial conditions in emerging market economies.

An early study on the effects of the Fed's QE policies on Asian economies is Morgan (2011), who finds that both rounds of QE between 2009 and 2011 triggered greater flows of capital into Emerging Asian markets. In his event study analysis of effects on long-term bond yields, Indonesia appears to be the only out of 11 Emerging Asian economies where yields were significantly affected.

Using quarterly data from 2004 to 2010, Moore et al. (2013) study the spillovers of US QE on 10year government bond yields of 10 EMEs, including 4 Asian EMEs (Indonesia, Korea, Malaysia, Thailand).Their estimates suggest that a decrease in the US 10-year Treasury yield by 10 basis points increased the foreign ownership share of EME debt by 0.4 percentage points with a negative effect of roughly 1.7 basis points on government bond yields.

Bowman et al. (2015) analyze the effects of the Fed's unconventional monetary policies on sovereign yields, foreign exchange rates and stock prices in 17 EMEs, 10 of which are from Asia (China, Hong Kong, India, Indonesia, Korea, Malaysia, Philippines, Singapore, Taiwan, Thailand). Their event study findings suggest that US monetary policy shocks significantly affect local currency sovereign yields in many countries but that the magnitude and the persistence of the effect varies greatly across EMEs.

Aizenman et al. (2016) follow a two-step estimation approach using monthly data. They find links of both policy interest rates and real effective exchange rates of EMEs with the major advanced economies over the last two decades. However, the linkages of stock market price changes and sovereign bond spreads between the center and periphery economies are found to be much less robust. 
Miyajima et al. (2014) use monthly data and a panel VAR model to investigate the pass-through of US monetary policy to five small open Asian economies (Indonesia, Korea, Malaysia, the Philippines and Thailand), covering two samples, 2003M1-2007M12 and 2009M06-2013M12. They find significant effects on long-term bond yields, suggesting that the control that domestic monetary authorities exert over long-term rates is compromised. They also find spillover effects on the growth of bank credit.

Tillmann (2016) estimates a Qual VAR model à la Dueker (2005) using monthly data for a set of Asia-Pacific and Latin American countries for the period from 2007:08 to 2013:03. His findings suggest that the Fed's QE policies increased capital inflows to EMEs, with positive effects on EME equity prices and negative effects on EME bond spreads. Tillmann (2016) also finds that the effects on EME bond spreads from a typical QE shock are similar to spillovers from a cut in the Fed Funds rate.

Overall, previous studies clearly show that unconventional US monetary policy in the wake of the 2007 crisis caused spillovers to Emerging Asian bond markets. We complement the existing research by making a number of new contributions in this paper. As mentioned earlier, in contrast to most previous research we investigate potential spillovers not only from the US but also from the Eurozone and Japan. Moreover, our estimation framework allows us to detect spillovers to sovereign long-term bond yields also between EMEs. The use of high frequency data allows us to analyze information that is otherwise lost in aggregation and analyze the time-variations in the spillovers and detect sudden changes in transmission magnitudes.

\section{Data and empirical approach}

\subsection{Data}

We use daily data of 10-year government bond yields for Indonesia, Korea, Philippines, India, China, Thailand, Taiwan, Malaysia, Hong Kong, the US, the Euro area and Japan, taken from Thomson Reuters. Due to data availability, the sample includes observations starting from 14.05.2003 and ends on 02.09.2016. Additionally, we include logs of daily VIX (CBOE Volatility Index) and oil prices as exogenous variables in the model in order to disentangle common global shocks. Since Asian markets close before the opening of the US market and half-way through the trading day of European markets, we adjust the data for the different time zones in line with 
Ohnsorge et al. (2014), matching US bond yields data with the average of the same-day and nextday data for Eurozone and with next-day data for Asia.4

Using high-frequency (daily) data, whose dynamics are by nature not affected by macroeconomic fundamentals, should have an advantage in identifying the spillovers in financial markets, where the news are priced rapidly, compared to lower frequency variables. Given a sufficiently large number of observations, we are also able to analyze the time-variations in the spillovers and detect sudden changes in transmission magnitudes.

Bond yields in advanced and emerging economies have moved closely together in recent years, despite differing macroeconomic conditions (Figure 1). We investigate whether this co-movement can be attributed to international monetary spillovers, e.g., whether and to what extent long-term interest rates in core countries affected long-term interest rates in emerging Asia’s countries.

Figure 1: Bond yields of Emerging Asian economies and major advanced economies

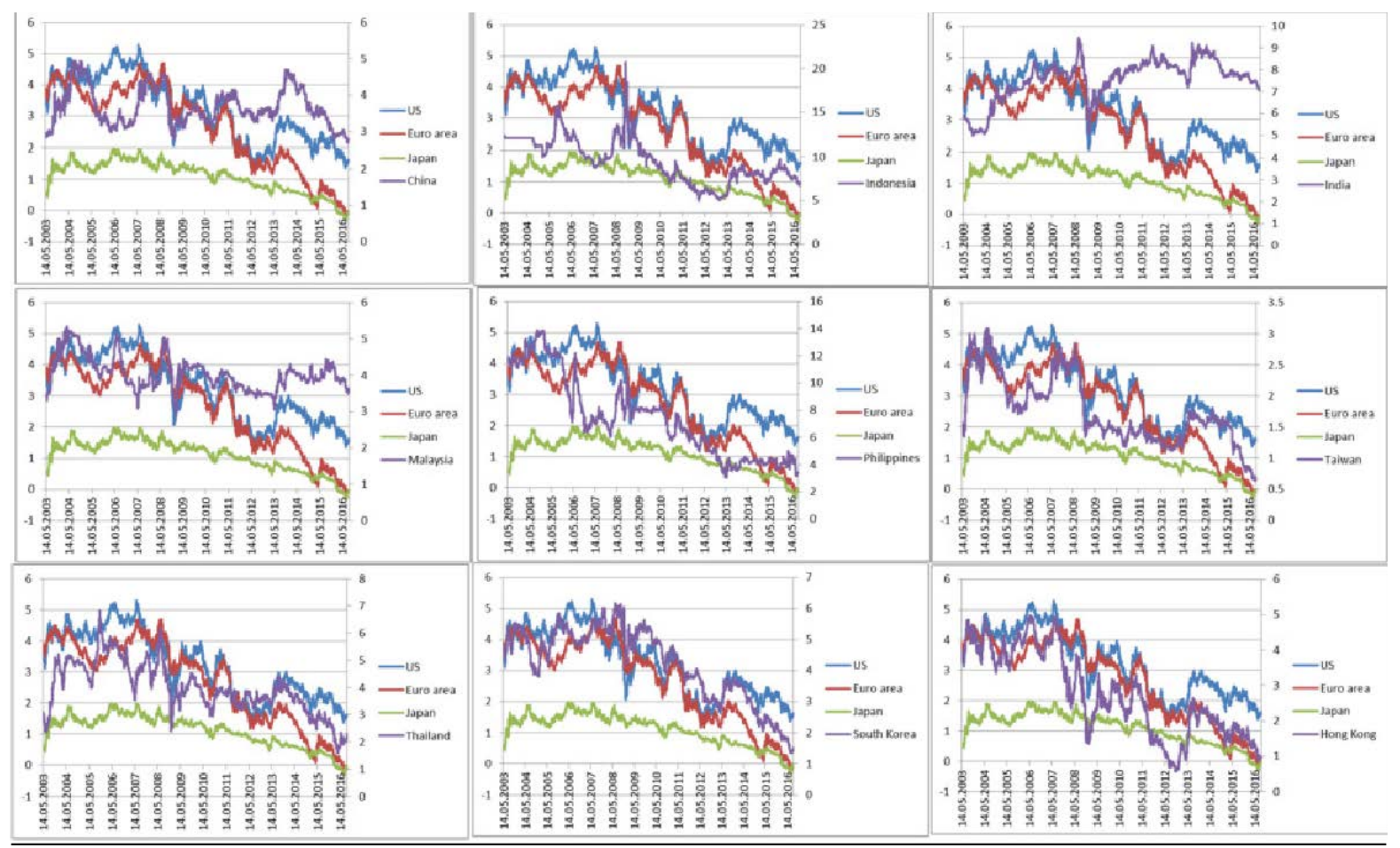

Note: For all graphs left y-axis is for US, Euro area and Japan bond yields, right y-axis is for the remaining data.

4 The estimations based on the alternative matching of data, where today's euro area bond yields correspond to the average of same- and next-day data for Asian yields, produce the same results. Moreover, in line with the arguments of Ehrmann et al. (2011) we've also performed estimations using a 2-day window. The main estimation results remain. The obtained results based on different data choices are available upon request. 
The three-month interbank interest rate and 10-year government bond yield for a country generally show common trends. However, short-term interest rates for some countries demonstrate small variation over particular time periods, posing difficulties for empirical analysis based on daily frequency data and, thus, on results' reliability. Moreover, daily three-month interbank rates for China are available only from 09.10.2006, which would also decrease degrees of freedom by VAR analysis. Thus, we will proceed with the analysis of long-run interest rates, namely 10-year government bond yields.

\subsection{Estimation approach}

In order to estimate the spillovers from bond markets in major advanced economies to Emerging Asia we follow the empirical approach proposed by Diebold and Yilmaz (2009, 2012) based on VAR variance decompositions.

Firstly, we estimate the VAR(p)5 model:

$$
\mathrm{x}_{\mathrm{t}}=\sum_{\mathrm{i}=1} \Phi_{\mathrm{i}} \mathrm{x}_{\mathrm{t}-\mathrm{i}}+\varepsilon_{\mathrm{t}}
$$

where $\varepsilon \in(0, \Sigma)$ is the i.i.d. errors vector.

A VAR-framework allows us to consider all variables as endogenous, which allows, first of all, considering non-trivial interlinkages between advanced economies in a proper way. Secondly, since EMEs represent a large and rising share of the global economy, there is growing evidence of spillbacks from EMEs to advanced economies, primarily through the trade, financial and commodity price channels (Rajan, 2014). Analysis conducted by the IMF suggests that spillback effects from EMEs tend to be modest, but could be larger in crisis periods. In addition, the effects are larger for countries or regions with greater trade exposure to EMEs, such as Japan and the Euro area (IMF, 2014).Taking into account above mentioned considerations the VAR model seems to be a reasonable choice.

According to economic theory it is plausible that interest rates are mean reverting, i.e. that they revert to a long-term equilibrium level as time goes by. However, empirical evidence to the stationarity of interest rates is mixed. In our sample, unit root tests indicate that bond yields in some

\footnotetext{
5 Since the yield data display a downward trend for some countries in the sample, we have also performed estimations with included time trend in the equation (1). The results remain robust to the inclusion of the trend. A graphical depiction of the dynamics of total spillover index and directional spillovers from major advanced countries to Emerging Asia of the specification with time trend is shown in the working paper version of this article (Belke et al., 2017).
} 
countries could be indeed considered as I(1) process, although these results are not unambiguous with respect to the choice of unit root test specification6. Moreover, a Johansen test indicates the existence of cointegrating relationships in our model, and thus, the first difference estimates might be biased because the error-correction term would be omitted. In this work, thus, we follow the approach of Sims et al. (1990), who showed that OLS estimates of VAR coefficients are consistent under a broad range of circumstances even if the variables are nonstationary, and estimate the VAR model in levels.

The moving-average representation of VAR model can be written as

$$
\mathrm{x}_{\mathrm{t}}=\sum \underline{\underline{\rho} \underline{\underline{Q}}}{ }_{0} \mathrm{~A}_{\mathrm{i}} \varepsilon_{\mathrm{t}-\mathrm{i}}
$$

where $A^{\mathrm{i}}=\sum^{\mathrm{k}=1} \Phi \stackrel{\mathrm{k}}{\mathrm{i}-\mathrm{k}}, \mathrm{A}_{0}$ is theidentity matrix $/ \mathrm{N} \times \mathrm{N}^{\text {and }} \mathrm{A}_{\mathrm{i}}=0$ for $\mathrm{i}<0$.

Our further analysis relies on variance decompositions, which allow assessing the fraction of the $\mathrm{H}$-step-ahead error variance in forecasting $\mathrm{x}_{\mathrm{i}}$ that is due to shocks tox $\mathrm{x}_{\mathrm{j}}$. In order to deal with contemporaneous correlations of VAR shocks, we use the generalized VAR framework, which produces variance decompositions invariant to ordering choice. The generalized approach allows correlated shocks, taking into account the historically observed distribution of errors. Thus, although the method does not identify the causality of spillovers, it relies on historical patterns to identify directionality.

The H-step-ahead forecast error variance decomposition7 is calculated as

$$
\begin{aligned}
& \theta_{\mathrm{ij}}^{\mathrm{g}}(\mathrm{H})={ }^{{ }^{\mathrm{r}_{\mathrm{it} 1} 1} \sum_{\mathrm{h}=0}^{\mathrm{H}-1}\left(\mathrm{e}_{\mathrm{i}}^{\mathrm{r}} \mathrm{A}_{\mathrm{h}} \mathrm{e}_{\mathrm{j}}\right)^{2}}, \\
& \mathrm{~h}=\mathrm{O} \quad \mathrm{i} \quad \mathrm{h} \quad \mathrm{h} \quad \mathrm{i}
\end{aligned}
$$

where $\Sigma$ is the variance matrix for the errors $\varepsilon, \sigma_{\mathrm{ii}}$ is the standard deviation of the error term for

the $i$-th equation of VAR and $e_{i}$ is a vector which contains one as $i$-th element and zeros otherwise. The Total Spillover Index (TSI) is then constructed as:

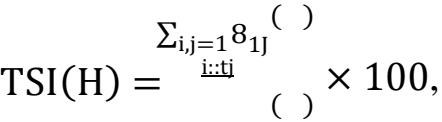

$$
\begin{aligned}
& \sum_{\mathrm{i}, \mathrm{j}=1} 8_{1 \mathrm{j}}
\end{aligned}
$$

6 The results of unit root and cointegration tests are available upon request.

7 In our baseline model specification we consider 15 working days ahead forecast error decompositions. 
where $\theta_{\mathrm{IJ}}^{\mathrm{g}}(\mathrm{H})$ is normalized value for $\theta_{\mathrm{ij}}^{\mathrm{g}}(\mathrm{H})$, so that $\left.\theta_{\mathrm{IJ}} \stackrel{\mathrm{g}}{\mathrm{H}}\right)=\frac{8_{\mathrm{ij}}()}{\left.\sum_{\mathrm{j}=1} 8_{\mathrm{ij}(\mathrm{C}}\right)}$. The total spillover index, thus, measures the contribution of spillovers of shocks across variables under consideration to the total forecast error variance.

In order to investigate the direction of spillovers in yields across countries, i.e. the portion of total spillover index that comes from $\mathrm{x}_{\mathrm{i}}$ to all other variables, the directional spillover is applied:

$$
\mathrm{DS}_{\mathrm{i} \rightarrow}(\mathrm{H})=\frac{\sum_{\mathrm{j}=1}^{\mathrm{j} 8_{\mathrm{J} 1}}(\mathrm{t})}{\sum^{\mathrm{j}=1}} \times 100
$$

This approach allows us to investigate changing-over-time dynamics of spillovers in the form of rolling regressions, and thus, the time variations of total and directional spillovers during the global financial crisis (GFC), the Euro crisis, and implementations of UMPs, which are of particular interest in our study.

\section{Empirical results}

Our empirical model can be considered as stable. (No root lies outside the unit circle; the max root is 0.999483 in modulus.) According to the Akaike information criterion (AIC), we have chosen a lag length of 48.

Our estimated generalized impulse responses for the model suggest that positive shocks to the US, the Euro area and Japan government bond yields result mostly in significant positive reactions of other countries’ bond yields during the next 15 working days (Figures 2 to 4). Only in a few cases we observe insignificant reactions, i.e., the impulse responses for China's bonds to US shocks; Indonesia and China's bonds to Euro area shocks; India, Indonesia, the Philippines and China's bonds to Japan's shocks.9 Altogether, our estimated generalized impulse response functions make sense with regard to significance and sign. In the following, we will concentrate on variance decompositions and the associated spillover measures.

\footnotetext{
8 As a robustness check, we selected a lag length of 2 according to the BIC The results remain robust to the lag length choice and are available in the working paper version of this article (Belke et al., 2017).

9 A discussion of our results for China follows below.
} 
Figure 2: Generalized impulse responses to shocks emanating from the US
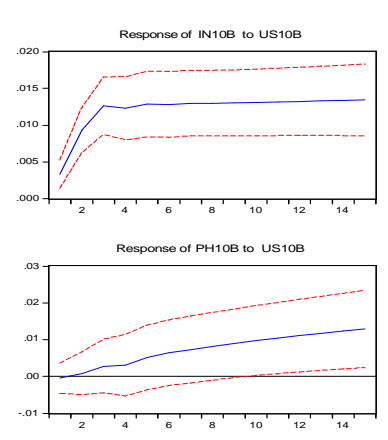

Response of $\mathrm{CH} 10 \mathrm{~B}$ to US10

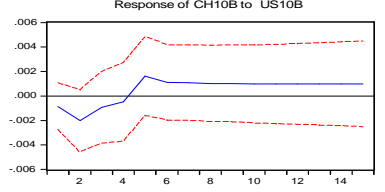

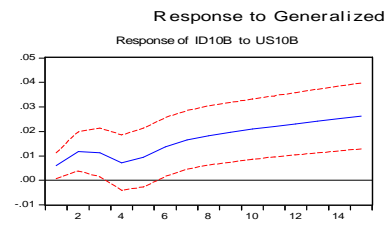

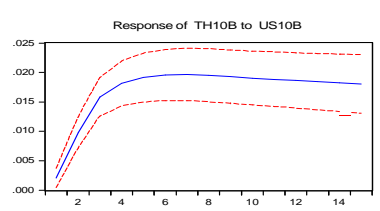

Response of US10B to US10

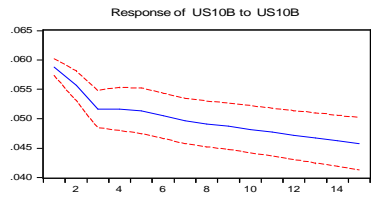

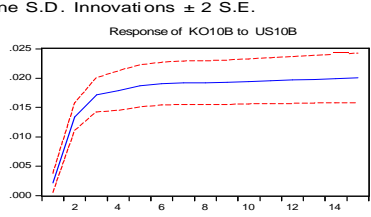

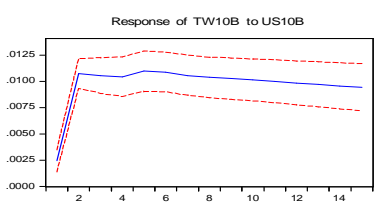

Response of EA10B to US10B

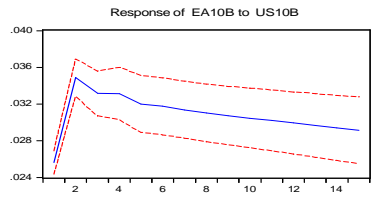

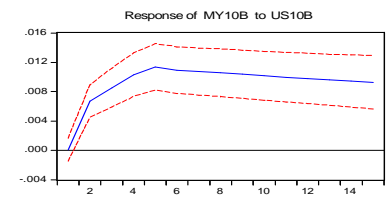

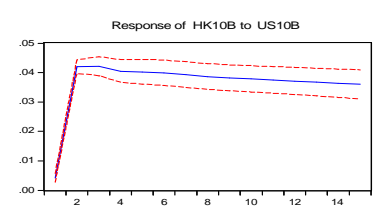

Response of JP1OB to US10B

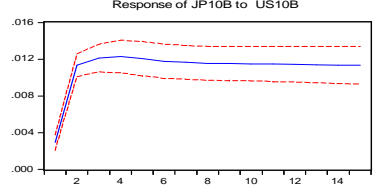

Figure 3: Generalized impulse responses to shocks emanating from the Euro area

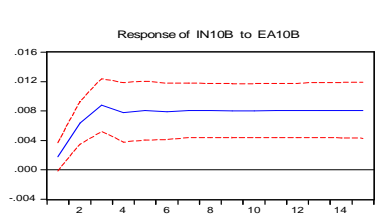

Response of PH1OB to EA108

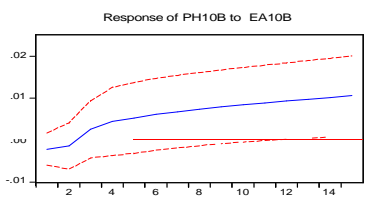

Response of $\mathrm{CH} 10 \mathrm{~B}$ to EA10

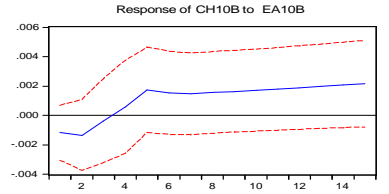

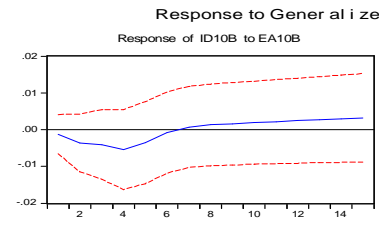
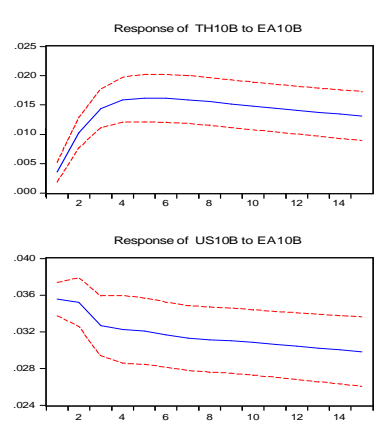
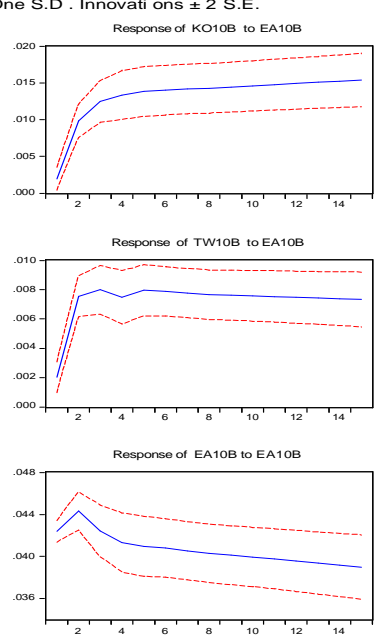
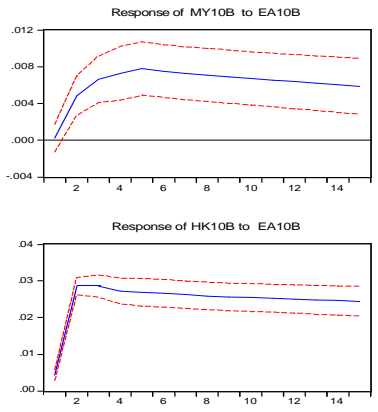

Response of JP10B to EA10B

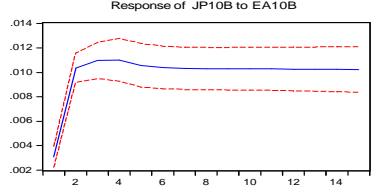

Figure 4: Generalized impulse responses to shocks emanating from Japan
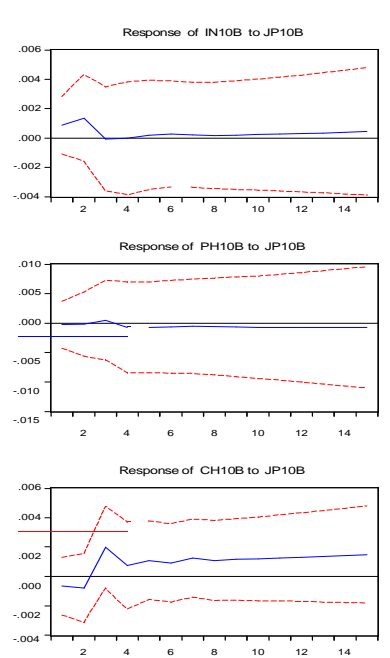
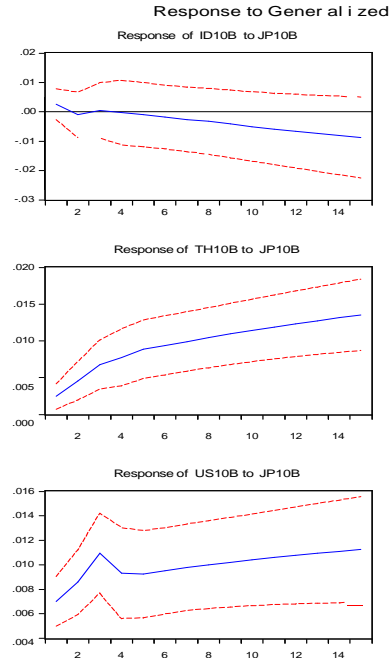
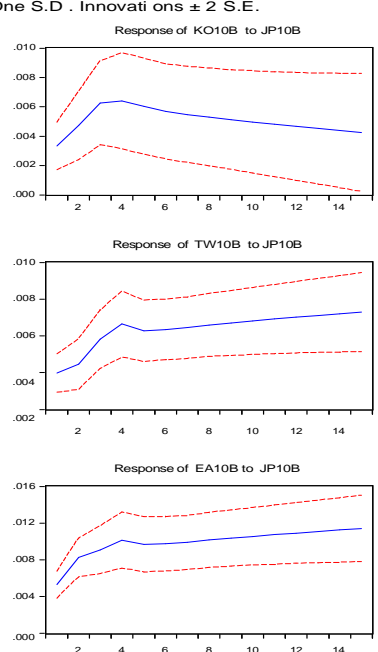
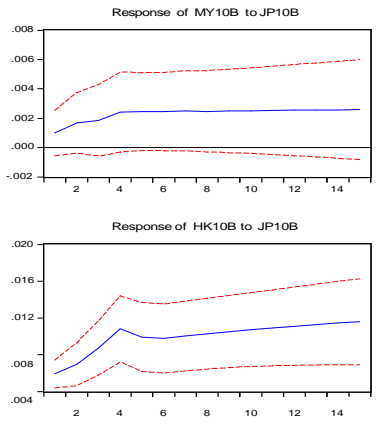

Response of JP1OB to JP1OB

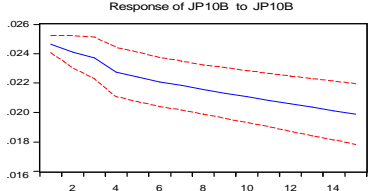


The Total Spillover Index (TSI) for all countries under consideration over the whole sample is 23.1\% (Table 1). Spillovers from major advanced economies (US, Euro area and Japan) explain a significant proportion of the variation in both advanced and emerging Asian economies' bond yields. About $14 \%$ of the variation in Asian EMEs' is attributable to spillovers from advanced economies, whereas only $5 \%$ are due to shocks generated by other emerging markets (remaining $81 \%$ are the contributions of own shocks). Almost $60 \%$ among the aforementioned spillovers from core to emerging markets can be traced back to the US, while nearly $30 \%$ and $10 \%$ stem from the Euro area and Japan respectively.

Table 1: Spillovers over the sample period May 14, 2003 to September 2, 2016

\begin{tabular}{|r|c|c|c|c|c|c|c|c|c|c|c|c|c|c|}
\hline & India & Indonesia & Korea & Malaysia & Philippines & Thailand & Taiwan & Hong Kong & China & Eurozone & Japan & USA & From Others \\
\hline India & 91.4 & 0.14 & 0.66 & 0.3 & 0.03 & 0.29 & 0.5 & 0.39 & 0.03 & 1.93 & 0.02 & 4.31 & 8.6 \\
\hline Indonesia & 0.11 & 90.24 & 0.11 & 0.2 & 5.36 & 2.39 & 0.05 & 0.05 & 0.1 & 0.05 & 0.23 & 1.09 & 9.8 \\
\hline Korea & 0.41 & 0.6 & 74.27 & 0.12 & 0.25 & 1.62 & 1.3 & 0.66 & 0.02 & 7.06 & 1.16 & 12.55 & 25.7 \\
\hline Malaysia & 0.56 & 0.65 & 1.25 & 85.87 & 0.31 & 1.43 & 0.72 & 2.6 & 0.03 & 2.17 & 0.42 & 3.99 & 14.1 \\
\hline Philippines & 0.08 & 1.2 & 0.14 & 0.33 & 97.27 & 0.03 & 0.11 & 0.18 & 0.01 & 0.16 & 0 & 0.49 & 2.7 \\
\hline Thailand & 0.38 & 1.46 & 1.66 & 0.86 & 0.24 & 76.45 & 2.02 & 2.06 & 0.01 & 4.78 & 2.94 & 7.14 & 23.5 \\
\hline Taiwan & 0.48 & 0.02 & 0.1 & 0.06 & 0.02 & 0.08 & 72.76 & 5 & 0.14 & 6.42 & 4.94 & 9.98 & 27.2 \\
\hline Hong Kong & 0.14 & 0.36 & 0.46 & 0.07 & 0.34 & 0.58 & 0.66 & 42.9 & 0.21 & 16.52 & 2.83 & 34.94 & 57.1 \\
\hline China & 0.61 & 0.23 & 0.65 & 0.07 & 0.07 & 0.51 & 0.44 & 0.06 & 97.08 & 0.09 & 0.16 & 0.03 & 2.9 \\
\hline Eurozone & 0.06 & 0.22 & 0.32 & 0.28 & 0.01 & 0.25 & 0.56 & 1.31 & 0.01 & 60.33 & 3.49 & 33.16 & 39.7 \\
\hline Japan & 0.03 & 0.13 & 0.5 & 0.23 & 0.01 & 0.12 & 0.93 & 1.37 & 0.17 & 13.25 & 67.41 & 15.83 & 32.6 \\
\hline USA & 0.17 & 0.9 & 0.18 & 0.07 & 0.02 & 0.25 & 0.45 & 1.41 & 0.03 & 27.02 & 3.07 & 66.44 & 33.6 \\
\hline Contribution includingown & 94.4 & 96.2 & 80.3 & 88.5 & 103.9 & 84 & 80.5 & 58 & 97.8 & 139.8 & 86.7 & 190 & $23.10 \%$ \\
\hline
\end{tabular}

Source: Own estimations.

According to Table 1, three “Asian tigers” - Hong Kong, South Korea and Taiwan - are the countries that are most prone to long-term interest rate spillovers from advanced countries. Bond markets in the Philippines and China are the least affected by other countries during the time under consideration. However, these results should be taken with caution, since Table 1 provides only “average” spillover effects over the time period starting from 2003. As we will see later in our time-consistency analysis, both China and Indonesia experienced significant spillovers from advanced countries since 2011.

China seems to be an exceptional case in our sample of countries, since shocks to China's yields also do not contribute to the variation of other countries' yields. That is, despite her weight in the regional and global economy, international spillovers from China’s bond markets appear limited 
for the time being, a result of the relatively small size of China's sovereign bond market and also a consequence of the still comprehensive controls on portfolio investment flows.

Spillovers from other emerging countries (namely from Philippines and Thailand) explain more variation in Indonesia's bond yields than spillovers from core countries. This could be seen as a sign of growing regional financial market integration. All other countries demonstrate strong linkages to the US and the Euro area, whereas spillovers to Emerging Asia from Japan are of lesser importance. Table 1 provides the static representation of total and directional spillovers, so that obtained measures could be considered as "average" over the whole sample. However, the time under consideration is highly turbulent on historical standards: for the last decade, the world economy has gone through many momentous occasions such as the global financial crisis of 2008, the European debt crisis, and advanced economies' implementation of UMPs. In order to analyze the time-variations in the spillovers and detect sudden changes in magnitudes, we continue with the analysis of spillover dynamics by means of rolling estimations (Figures 5 and 6).10

Figure 5: Dynamics of total spillover index and directional spillovers from major advanced countries to Emerging Asia

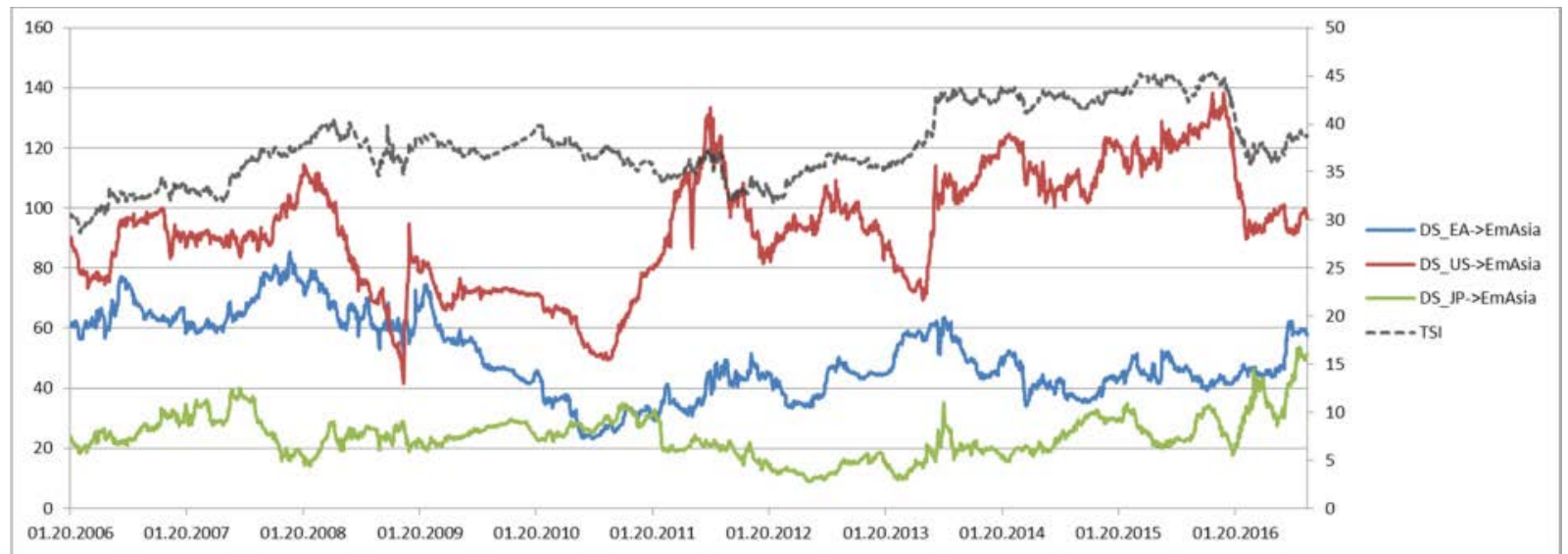

Note: Left y-axis is for the directional spillovers data, right y-axis is for the TSI data.

The spillovers are indeed not constant over time. From Table 1 we observe that a large portion of the "average" total spillover index belongs to the spillovers across advanced countries, indicating highly integrated financial markets across advanced countries and their strong inter-linkages. Since in this study we are particularly interested in spillovers to Emerging Asia, we continue with an

10 The rolling window is chosen to be 700 working days. 
analysis of directional spillover indices from each of the major advanced economies to Asian economies.

Figure 6: Spillovers to individual Asian economies

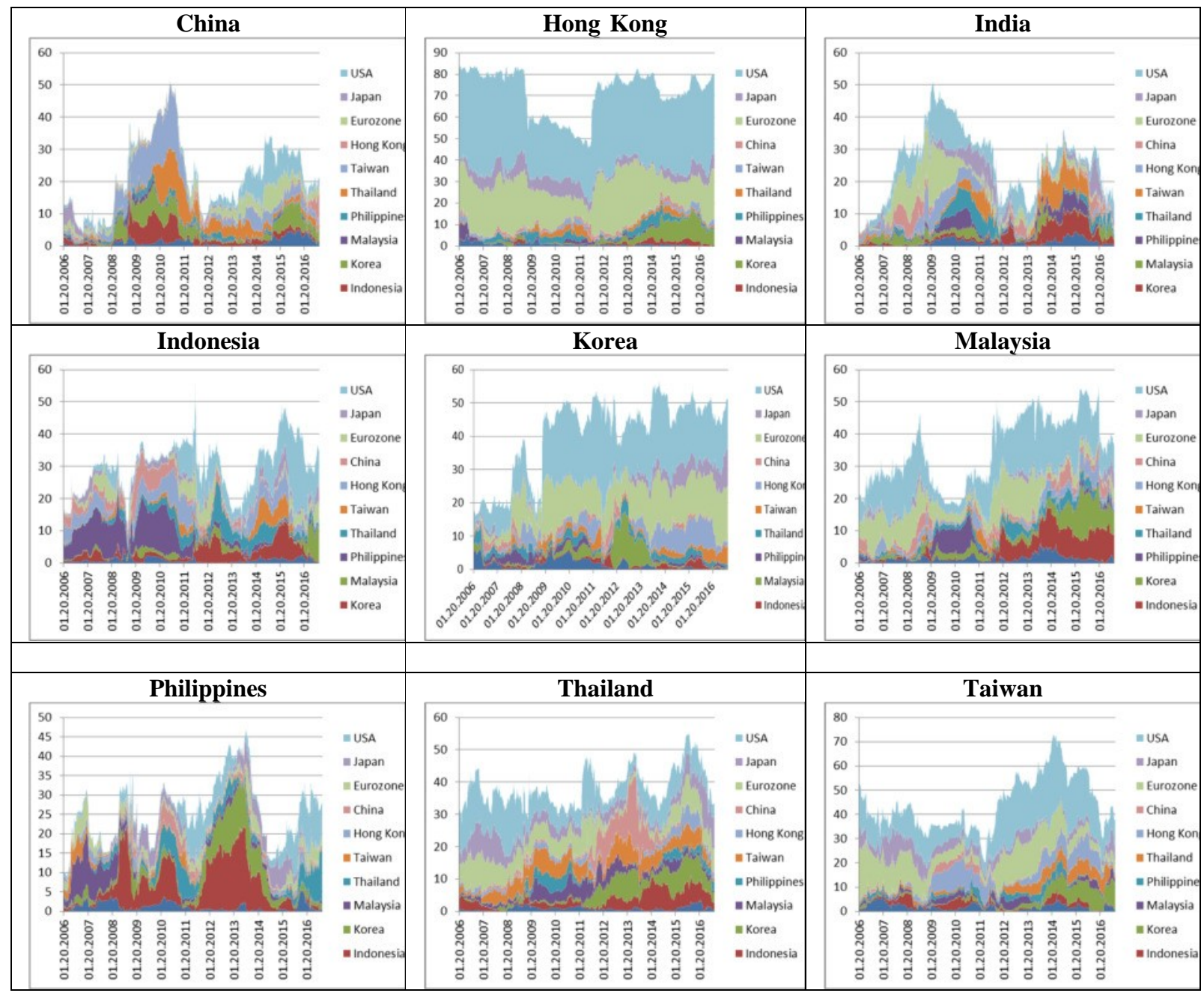

Figure 6 shows the long-term interest rate pass-through for each country from all other countries under consideration. Along with the contributions of advanced countries, the interlinkages in the regional bond markets are also displayed. While for Hong Kong and South Korea bond markets spillovers come mainly from advanced economies, a relative large portion of the spillovers facing Malaysia and the Philippines come from Emerging Asia’ regional bond markets. 
Spillovers from the US11

Figure 5 shows that in the pre-2008 global crisis period the spillovers from the US to Emerging Asia were increasing. However, in 2008 the contribution of US bond market shocks to Emerging bond markets' variation started to decrease. This in turn has changed abruptly with the announcement of the QE1 program and the index increased almost immediately from near 90 to 140 points. The effect did not appear to be stable over time and spillovers were slowly decreasing since then. This has changed once again in the times of QE2 announcements, and the spillovers from US bond market grew almost steadily until the end of the program. Alongside the first forward guidance and operational twist announcements, the spillovers remained on the same level, and then decreased. The time span between the forward guidance announcement on January 25, 2012, and Bernanke's testimony to the Congress (known as "taper tantrum”) on May 22, 2013, was quite volatile, whereas the latter resulted in growth of US-Emerging Asia yields spillovers. After the QE3 program was finished and until the Fed had increased the interest rates, the US yields spilled intensively over emerging Asia. Taken together, from the dynamic pattern we clearly observe that sudden changes of intensity in the US bond market spillovers coincide with specific policy announcements. The increase of the spillovers during the implementations of low interest rate policies is in line with the search-for-yield hypothesis (Belke and Rees, 2014). The results are also consistent with the findings of Obstfeld (2015) that US monetary policy has been to an increasing extent transmitted to Asia through global bond markets.

So far, we have analyzed the dynamic behavior of US bond market spillover to Emerging Asia bonds taken all together. The next question which arises is whether countries in Emerging Asia display common reactions to US long term interest rates shocks. Thus, we will have a look at the pairwise directional spillovers from US to each of the Asian country under consideration (Figure 7).

11 An overview of monetary policy events in the US, Japan and the Euro area is provided in the working paper version of this article (Belke et al., 2017). 
Figure 7: Pairwise directional spillovers from the US to India, Thailand, Malaysia, Taiwan, Hong Kong, South Korea, the Philippines, Indonesia and China
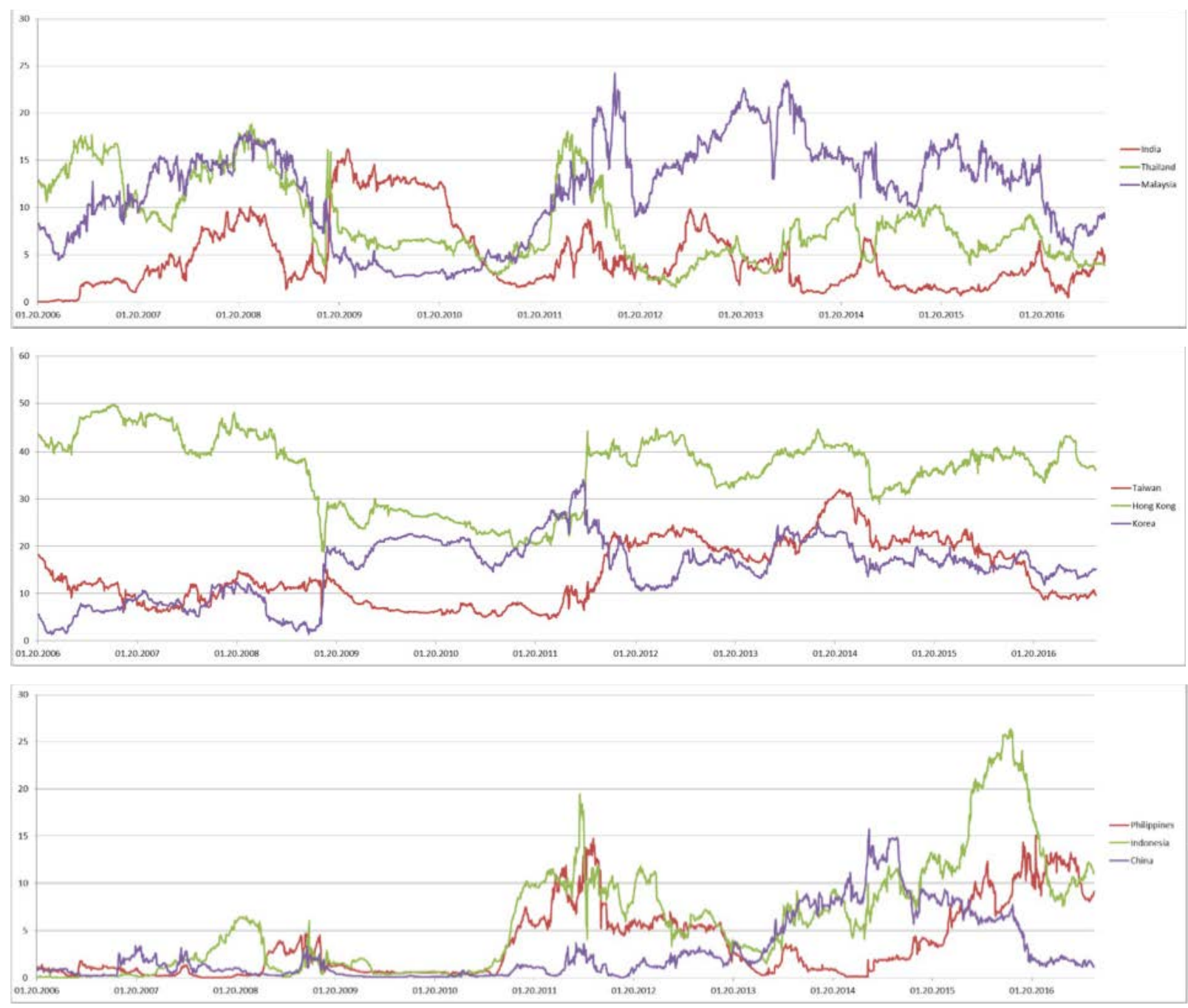

Indonesia, China and the Philippines started to be exposed to relative large spillovers from US government bonds only in 2011, thus the results obtained for these countries from Table 1 "hide" last years' developments. From May 2013, the time of Bernanke’s tapering speech, Indonesia was hit particularly hard among South-East Asian markets in 2013; its heavy reliance on external finance and declining exports due to weak commodity prices left it vulnerable to external shocks, making it one the so-called "Fragile Five" (along with Brazil, India, Turkey and South Africa). Hong Kong, whose currency is fixed to the US dollar through a currency board arrangement, also experienced sizable spillover effects from the US. 
Spillovers from Japan

Figure 5 demonstrates that after the introduction of the BOJ's Quantitative and Qualitative Monetary Easing (QQE) policy in April 2013, the total spillover index from Japan has been in an upward trend. However, directional spillovers from Japan are shown to be very heterogeneous across countries, although Taiwan, Korea and Hong Kong show to some extent similarities in reactions to Japanese shocks (Figure 8). The election of Prime Minister Abe in December of 2012 and the BOJ's anticipated regime shift with the arrival of its new governor Haruhiko Kuroda in March 2013 caused quite sizable spillovers to the Philippine, Indonesian and Thai bond yields but did not have any notable impact on China or India. The BOJ's decision to impose negative rates on certain reserves that financial institutions deposit at the central bank in January 2016 had more sizable effects across the region.

Figure 8: Pairwise directional spillovers from Japan to India, Thailand, Malaysia, Taiwan, Hong Kong, Korea, the Philippines, Indonesia and China
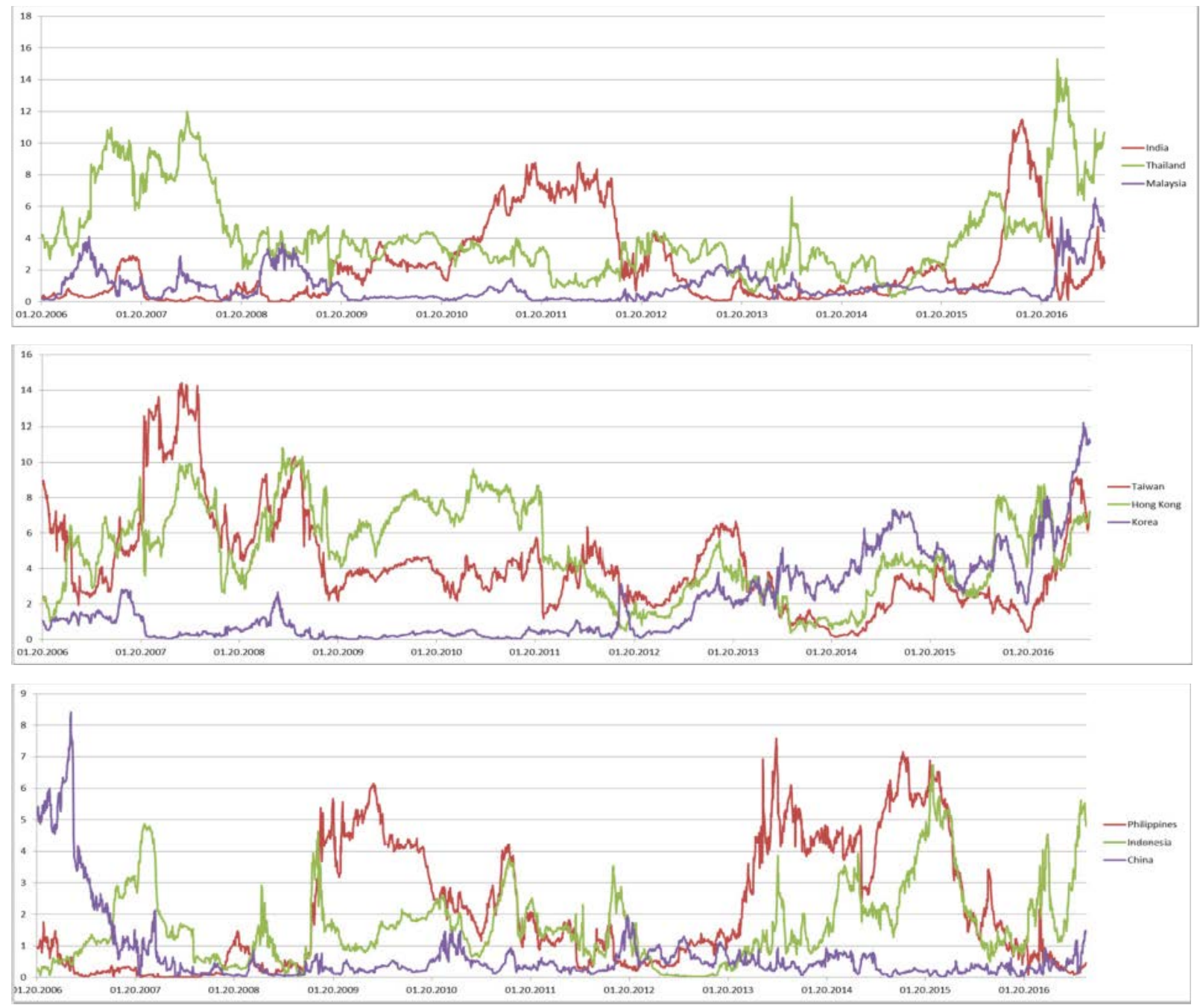
Spillovers from the Euro area

Total directional spillovers from the Eurozone were on the decline between 2008 and the first quarter of 2010. However, with the outbreak of the euro crisis in spring 2010, spillovers from the Eurozone started to increase again (Figure 5), even though they never reached the pre-2008 crisis level. Similarly to Japan's case, one can notice a recent increase in contributions of Eurozone yield shocks to the Asian EMEs yields, corroborating the view of the Asian Development Bank (2014) that more expansionary measures introduced by BOJ and ECB could offset the impact on liquidity conditions caused by the end of the Fed's zero interest rate policy in December 2015.

Directional spillovers from the Euro area vary greatly across Emerging Asian countries and are volatile. Figure 9 shows significant spillovers from the Eurozone to India starting 2007 till 2009, firstly, due to increasing foreign institutional investment in 2007-08, and secondly, due to withdrawal of capital from India's financial markets in 2008-09. Since then the spillovers from the euro bond market decreased until the ECB started to implement its Securities Markets Program (SMP) in May 2010. From the second half of 2010, the spillovers remained stable at a low level. Euro area spillovers to Thailand were relatively stable (with a slight increase due to SMP implementation) over the period up until mid-2011, when the Thai economy was hit hard by a flood crisis, which apparently coincided with a drop of spillovers from Euro area. However, after ECB President Mario Draghi's now famous "Whatever it takes” speech on July 20, 2012, the spillovers to Thailand started to continuously increase again. ECB announcements of a number of nonstandard monetary policy measures in early August 2011 resulted in an increase of spillovers to Malaysia, Philippines, Taiwan, Hong Kong and Korea. The July 2012 speech by Mario Draghi also resulted in a substantial increase of spillovers to China, Hong Kong, Taiwan and South Korea. The start of the ECB's Expanded Asset Purchase program in 2015 resulted in a gradual increase in pairwise directional spillovers to Indonesia, Philippines, Hong Kong and Korea. 
Figure 9: Pairwise directional spillovers from the Euro area to India, Thailand, Malaysia, the Philippines, Indonesia, China, Taiwan, Hong Kong and South Korea
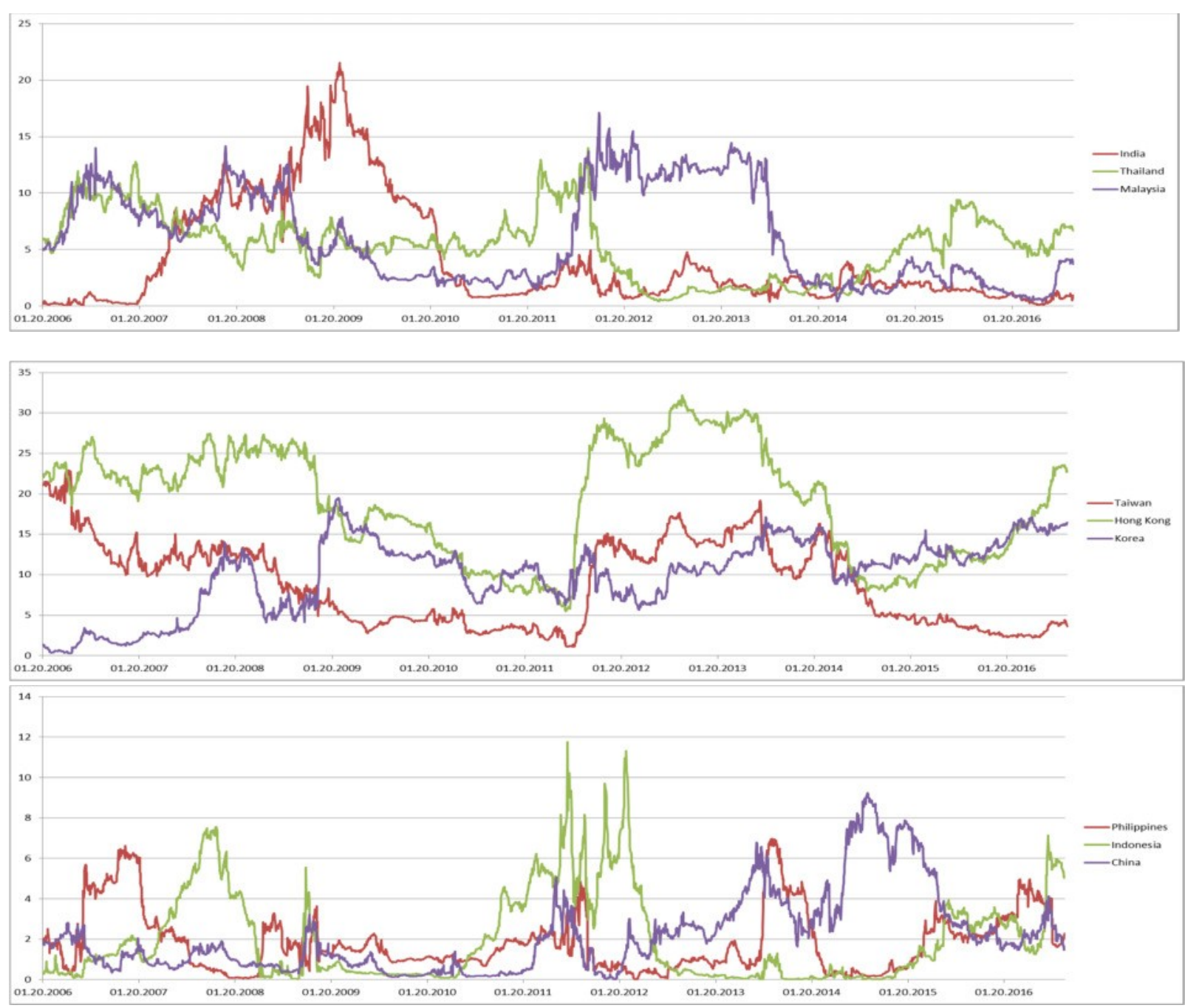

\section{Spillovers from China}

Given the growing role of the Chinese economy in the region and the world economy at large, we may briefly look into spillovers from China's bond yields to yields of other Emerging Asian economies. As already mentioned when we discussed the results for our spillover index for all countries for the whole sample period reported in Table 1, long-term bond yields across Emerging Asia have stayed completely unaffected by Chinese bond yields. Given that the spillover index presented is an average for a period ranging from May 14, 2003 to September 2, 2016 - a period during which the size of China’s local currency bond markets increased substantially (from US\$ 371.19 bn or $23.9 \%$ of GDP in June 2003 to US\$ 4,969 bn or 45.9\%of GDP in September 2016) 
and capital controls were gradually relaxed, one may expect that spillovers have increased over time. However, as can be seen in Figure 10, this has not been the case. The spillover index has remained at a very low level throughout, suggesting that even in September 2016, Chinese bond market developments have no impact on the other markets in the region. This does of course not imply that developments in Chinese financial markets do not matter for the rest of Asia - as illustrated by the stock market upheavals in 2015-16 they do -, but for the time being bond markets apparently do not. Looking forward, one may expect this to change with a growing importance of the renminbi-denominated assets in regional financial markets and a potential further opening up of China’s capital markets.

Figure10: Total directional spillover from China to Emerging Asia

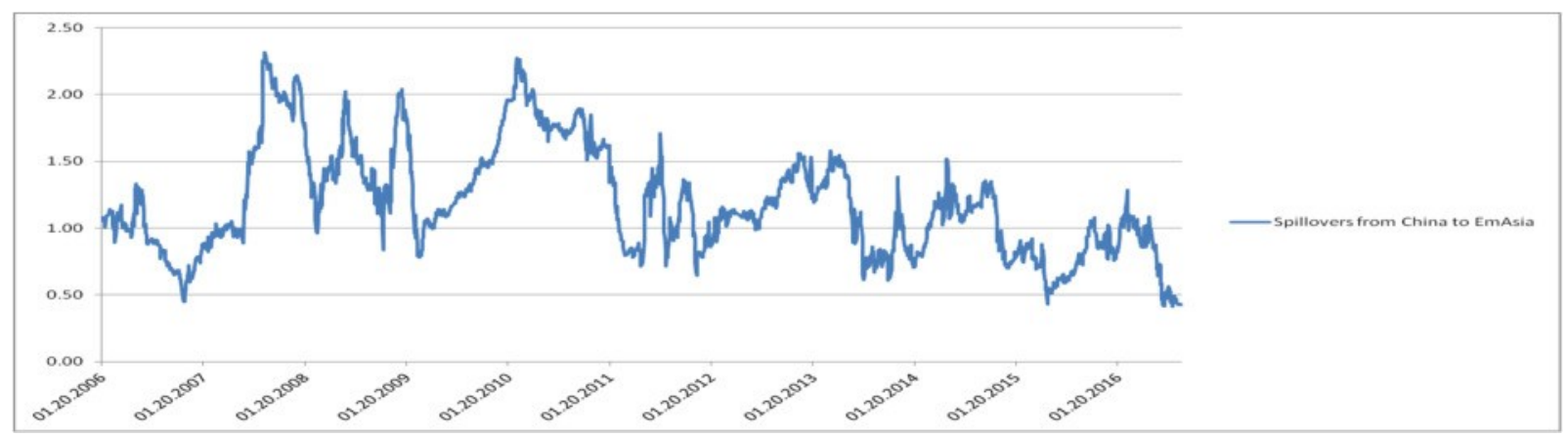

To sum up, our chosen estimation approach has allowed us to trace the evolution of spillovers over time. For example, one can see that for China, Indonesia and Philippines monetary independence from US and Eurozone shocks becomes compromised only starting 2010-2011, whereas other Emerging Asian countries were more or less prone to spillovers from US bond markets over the whole time period under consideration. Thus, we have been able to identify potential structural breaks which should be taken into account in further research on this topic.

A panel of robustness tests was conducted in order to check whether our results are sensitive to the model specification and the choice of model parameters. Firstly, we have included the VIX (as well as oil prices) in an endogenous set of variables, instead of considering it as exogenous control variable as it was done in our baseline VAR-model. Bellas et al. (2010), among others, argue that the measures of market sentiment and global risk aversion explain a large fraction of EME sovereign bonds. However, the global risk aversion itself might be influenced by changes in advanced countries' interest rates (Rey, 2013; Rey, 2014), and thus, considering VIX as endogenous variable might be more appropriate. Secondly, we have modified our model in order 
to control for the possible linkages between bond yields and exchange rates. Gadanecz et al. (2014) found that exchange rate risk is a key determinant of EME sovereign bond yields, and could amplify the negative impacts of domestic and international factors on bond yields. Thirdly, we have tested our model with respect to the different choices of model parameters - alternative lag orders of 2 and 8; 10 and 20 working days forecast horizons. Because of space constraints, our robustness checks cannot be reported and fully discussed here, but they are available in the working paper version of this study (Belke et al., 2017). Overall, our model passed successfully the sensitivity checks and we thus consider our basic findings as reliable.

\section{Conclusions}

In this contribution we have investigated the extent to which changes of long-term interest rates in major advanced economies have affected long-term government bond yields in Emerging Asia. To gauge long-term interest spillover effects, we have employed VAR variance decompositions derived from high frequency data. Our results reveal that sovereign bond yields in Emerging Asia at times responded significantly to changes to US and Euro area bond yields, although the magnitudes turned out to be heterogeneous across countries. This may indicate to the different transmission and adjustment mechanisms in Emerging Asian economies, which could in turn explain the cross-countries differences in macroeconomic performance, e.g., output and credit growth. Spillovers from Japan were also sizable for a few Southeast Asian countries, but at a lower magnitude. In all cases, the magnitude of spillovers varied over time. The pattern of these variations can partially be attributed to the implementation of different unconventional monetary policy measures in advanced countries. Generally, we observe the intensification of spillover effects on emerging markets during the UMPs, supporting the notion of the "New Normal" for the recent international financial system.

Our finding clearly suggest that the notion of a “decoupling” of Emerging Asian economies and financial markets from the US and also Europe remains an illusion. Spillovers from US bond markets in particular were sizable already before the start of the Fed's UMPs, and they have become larger since. It is also notable that we do not find any evidence of a growing importance of spillovers from China's bond markets to the rest of region.

While calls have been made by Asian policy makers for greater international monetary coordination to limit such spillovers (e.g., Rajan, 2014), the mandate for achieving domestic economic targets for both the Fed and the ECB effectively limits substantial internationalmonetary 
cooperation to exceptional circumstances, such as financial upheavals of a global scale. The implication is that Emerging Asian economies will have to continue learning to live with such policy spillovers.12 If central banks are constrained in their ability to control domestic long-term interest rates, the whole arsenal of macro-prudential policies has to be used to try to control domestic credit creation and safeguard long-term financial stability.

\section{References}

Aizenman, J., M.D. Chinn and H. Ito (2016), "Monetary Policy Spillovers and the Trilemma in the New Normal: Periphery Country Sensitivity to Core Country Conditions," Journal of International Money and Finance 68, 298-330.

Asian Development Bank (2014), Asia Bond Monitor, https://asianbondsonline.adb.org/documents/abm_sep_2014.pdf.

Bauer, M.D. and G.D. Rudebusch (2014), "The Signaling Channel for Federal Reserve Bond Purchases,” International Journal of Central Banking 10(3), 233-289.

Belke, A., I. Dubova and U. Volz (2017), "Bond Yield Spillovers from Major Advanced Economies to Emerging Asia,” SOAS Department of Economics Working Paper No. 203, London: SOAS University of London.

Belke, A. and A. Rees (2014), "Globalisation and Monetary Policy - A FAVAR Analysis for the G7 and the Euro Area," North American Journal of Economics and Finance 29, 306-321.

Belke, A. and F. Verheyen (2014), “The Low Interest Rate Environment, Global Liquidity Spillovers and Challenges for Monetary Policy Ahead, Comparative Economic Studies 56, S313-334.

Belke, A., D. Gros, and T. Osowski (2016), "Did Quantitative Easing Affect Interest Rates Outside the US? - New Evidence Based on Interest Rate Differentials,” CEPS Working Document 416, Centre for European Policy Studies, Brussels, January.

Bellas, D., M.G. Papaioannou and I. Petrova (2010), "Determinants of Emerging Market Sovereign Bond Spreads: Fundamentals vs Financial Stress,” IMF Working Paper No. 10/281, Washington DC: International Monetary Fund.

Bernoth, K., M. Hachula, M. Piffer, and M. Rieth (2016), "Effectiveness of the ECB Programme of Asset Purchases: Where Do We Stand? In-Depth Analysis,” Politikberatung Kompakt No. 13, Berlin: Deutsches Institut für Wirtschaftsforschung.

Bowman, D., J.M. Londono and H. Sapriza (2015), "US Unconventional Monetary Policy and Transmission to Emerging Market Economies," Journal of International Money and Finance 55, 27-59.

Caceres, C., Y. Carrière-Swallow, I. Demir and B. Gruss (2016), "U.S. Monetary Policy Normalization and Global Interest Rates,” IMF Working Paper No. 16/195, Washington, DC: International Monetary Fund.

12 For a recent analysis of East Asian economies’ efforts at dealing with QE spillovers see Saiki et al. (2016). 
Chen, Q., A. Filardo, D. He and F. Zhu (2012), "International Spillovers of Central Bank Balance Sheet Policies," in: BIS (ed.), Are Central Bank Balance Sheets in Asia too Large? BIS Paper No. 66, Basel: Bank for International Settlements, 230-274.

Christensen, J.H.E. and S. Krogstrup (2015), "Transmission of Quantitative Easing: The Role of Central Bank Reserves,” FRBSF Working Paper No. 2014-2018, San Francisco, CA: Federal Reserve Bank of San Francisco.

Christensen, J.H.E. and G.D. Rudebusch (2012), "The Response of Interest Rates to U.S. and U.K. Quantitative Easing,” The Economic Journal 122, F385-F414.

Diebold, F.X. and K. Yilmaz (2009), "Measuring Financial Asset Return and Volatility Spillovers, with Application to Global Equity Markets,” The Economic Journal 119, 158-171.

Diebold, F.X. and K. Yilmaz (2012), "Better to Give Than to Receive: Predictive Directional Measurement of Volatility Spillovers,” International Journal of Forecasting 28(1), 57-66.

Dueker, M. J. (2005), “Dynamic Forecasts of Qualitative Variables,” Journal of Business and Economic Statistics 23, 96-104.

Gadanecz, B., K. Miyajima and C. Shu (2014), "Exchange Rate Risk and Local Currency Sovereign Bond Yields in Emerging Markets”, BIS Working Paper No. 474, Basel: Bank for International Settlements.

Edwards, S. (2012), “The Federal Reserve, Emerging Markets, and Capital Controls: A High Frequency Empirical Investigation,” NBER Working Paper No. 18557, Cambridge, MA: National Bureau of Economic Research.

Ehrmann, M., M. Fratzscher and R. Rigobon (2011), "Stocks, Bonds, Money Markets and Exchange Rates: Measuring International Financial Transmission,” Journal of Applied Econometrics 26, 948-974.

Eichengreen, B.J. and P. Gupta (2015), “Tapering Talk: The Impact of Expectations of Reduced Federal Reserve Security Purchases on Emerging Markets,” Emerging Markets Review 25, $1-15$.

Gonzalez-Rozada, M. and E. Levy-Yeyati (2008), “Global Factors and Emerging Market Spreads,” The Economic Journal 118 (November), 1917-1936.

Gros, D., C. Alcidi and W.P. De Groen (2015), "Lessons from Quantitative Easing: Much Ado about So Little?” CEPS Policy Brief No. 330, Brussels: Centre for European Policy Studies.

Hofmann, B. and E. Takáts (2015),“International Monetary Spillovers,” BIS Quarterly Review September, 105-118.

IMF (2014), “IMF Multilateral Policy Issues Report”, 2014 Spillover Report, Washington, DC: International Monetary Fund.

Jaramillo, L. and A. Weber (2012):"Bond Yields in Emerging Economies: It Matters What State You Are In,” IMF Working Paper No. 12/198, Washington, DC: International Monetary Fund.

Krishnamurthy, A. and A. Vissing-Jorgensen (2011), “The Effects of Quantitative Easing on Longterm Interest Rates,” Brookings Papers on Economic Activity Fall, 215-265.

Lavigne, R., S. Sarker and G. Vasishtha (2014), "Spillover Effects of Quantitative Easing on Emerging-market Economies,” Bank of Canada Review Autumn, 23-33. 
Miyajima, K., M.S. Mohanty and J. Yetman (2014), "Spillovers of US Unconventional Monetary Policy to Asia: The Role of Long-term Interest Rates,” BIS Working Paper No 478, Basle: Bank for International Settlements.

Moore, J., S. Nam, M. Suh and A. Tepper (2013), "Estimating the Impacts of U.S. LSAPs on Emerging Market Economies’ Local Currency Bond Markets”, FRBNY Staff Report No. 595, New York, NY: Federal Reserve Bank of New York.

Morgan, P. (2011), “Impact of US Quantitative Easing Policy on Emerging Asia,” ADBI Working Paper No. 321, Tokyo: Asian Development Bank Institute.

Obstfeld, M. (2015), “Trilemmas and Trade-offs: Living with Financial Globalisation,” BIS Working Paper No. 480, Basle: Bank for International Settlements.

Ohnsorge F., Wolski, M. and Y. S. Zhang (2014), "Safe Havens, Feedback Loops, and Shock Propagation in Global Asset Prices,” IMF Working Paper, WP/14/81.

Park, C.-Y. (forthcoming), “Developing Local Currency Bond Markets in Asia,” in: U. Volz and N. Yoshino (eds.), Handbook of Banking and Finance in Asia, London and New York: Routledge.

Rajan, R.G. (2014), “Competitive Monetary Easing: Is It Yesterday Once More?” Speech at the Brookings Institution, Washington, DC, April 10, https://www.brookings.edu/wpcontent/uploads/2016/07/rajan_remarks_at_brookings.pdf

Rey, H. (2013), "Dilemma Not Trilemma: The Global Financial Cycle and Monetary Policy Independence,” prepared for the 2013 Jackson Hole Meeting.

Rey, H. (2014), “The International Credit Channel and Monetary Autonomy,” Mundell-Fleming Lecture, International Monetary Fund, 13 November.

Roley, V. Vance and Gordon H. Sellon, Jr. (1995), "Monetary Policy Actions and Long-Term Interest Rates,” Federal Reserve Bank of Kansas City Economic Review Fourth Quarter, 73-89.

Saiki, A., P. Chantapacdepong and U. Volz (2016), "Dealing with Quantitative Easing Spillovers in East Asia: The Role of Institutions and Macroprudential Policy,” ADBI Working Paper No. 604, Tokyo: Asian Development Bank Institute.

Sims, C. A., Stock, J. H., and M.W. Watson (1990), "Inference in Linear Time Series Models with Some Unit Roots,” Econometrica, 58(1), 113-44.

Tillmann, P. (2016), "Unconventional Monetary Policy and the Spillovers to Emerging Markets,” Journal of International Money and Finance 66, 136-156.

Wright, J.H. (2012), "What Does Monetary Policy Do to Long-Term Interest Rates at the Zero Lower Bound?” The Economic Journal 122 (564), F447-F466. 